\title{
CULTURAL DIFFERENCES IN CREATIVE REACTIONS TO AN AMBIGUOUS STIMULUS
}

\author{
Petra POTMĚŠILOVÁ ${ }^{1}$, Miloň POTMĚŠIL ${ }^{2 *}$ \\ ${ }^{1}$ Palacký University, Theological Faculty of Cyril and Methodius, Department of Christian Education, \\ Kř́žkovského 511/8, 77147 Olomouc, Czech Republic \\ ${ }^{2}$ Palacký University, Faculty of Education, Institute of Special Pedagogy Studies, \\ Kř́žkovského 511/8, 77147 Olomouc, Czech Republic
}

Received 3 April 2018; accepted 31 March 2019

\begin{abstract}
Art therapy has been used in the Czech Republic since the 1950s, and the only thing that has changed over the course of time has been the target group to which art therapy is applied. Art therapy is currently used in three key areas: psychology, social work, and education, or, more precisely, special education. The purpose of the present study is to demonstrate the specific cultural differences during the use of art therapy procedures in the field of education, specifically during work with creativity. The target group for the research consisted of university students from Poland and the Czech Republic. The students were all presented with the same ambiguous stimulus, to which they were to respond artistically. The individual artistic responses were then classified into specific categories, and cultural differences were subsequently evaluated and described.
\end{abstract}

Keywords: ambiguous stimulus, artphiletics, cognitive penetrability, creativity, cultural aspects, educational process.

\section{Introduction}

The use of art therapy as a way of working with clients dates back to the 1950s (Case \& Dalley, 2014; Aron Rubinová, 2008; Malchiodi, 2012), and the spectrum of target groups has gradually broadened over time. In the Czech Republic (CZR), as in the rest of the world, art therapy was formerly used with individuals with a psychiatric diagnosis. The clientele in the field of special education became a target group for art therapy in the second half of the 20th century. Art therapy is currently applied in three key areas: psychology, social work, and education. In the field of psychology, art therapy is mainly used with clients with various psychiatric diagnoses (Aron Rubinová, 2008) and also to support the treatment of specific clients - for example, during the rehabilitation of the family (Sutherland, 2011) and in connection with external and internal relationships in families. A holistic approach to the client

${ }^{\star}$ Corresponding author. E-mail: mvpotmesil@gmail.com 
is essential (Karkou \& Sanderson, 2006). In the field of social work, art therapy is mainly used with clients who have problems with dependence and addictive behaviour; it is also used in psychosocial rehabilitation (Spaniol, 2012). The use of art therapy in education has a fairly long tradition in the CZR (since the 1970s) and can be considered quite specific. The ground-breaking publication "Artphiletics from the Expression to Dialogue in Upbringing" (in Czech: "Artefiletika - od výrazu k dialogu ve výchově”) by Jan Slavík (2001) was published at the end of the 1990s. Art therapy and artphiletics began to be distinguished from each other in the CZR. Both disciplines use means that relate to art during work with individuals, but artphiletics plays a role in the educational field, art therapy in the fields of psychology, psychiatry, and social work.

Art therapy undoubtedly has its place in the field of education (Campbell, 1998; Lowenfeld \& Brittain, 1987). As mentioned above, in the CZR, the field of Artphiletics began to be promoted in the field of education from the 1990s. Artphiletics, as a separate discipline, arises on the basis of professional discussions just above the use of art therapy in pedagogy. The basic questions that have been asked are:

- what the competences of the actors in the art therapy process are,

- what the nature of the order is - what is expected from art therapeutic approaches.

Slavík (1997) summarises the results of the discussion and states that the aim of distinguishing these two disciplines is to preserve the distinctiveness of art therapy as an area that is primarily intended for people with mental illness. Artphiletics can then convey the sense of art on the one hand and, on the other hand, it can be an appropriate screening of problems that are well solved at the pedagogical level.

Artphiletics is a discipline that is equivalent to art therapy in one aspect but differs from it in another. Like art therapy, artphiletics applies the methodological principle of a combination of creative expression (through what are known as expressive games) and investigative reflection and dialogue (what is termed reflective dialogue; see below). However, in contrast to art therapy, artphiletics uses this principle not for therapeutic purposes, but for educational or salutogenic purposes (Slavík, 1997). Its goal is therefore not to provide treatment, but to contribute to self-awareness and to the development of personality and positive characteristics in the field of education. It can also be used as part of the prevention of social and other pathologies.

Artphiletics can be described as an educational concept whose primary principle is a combination of an expressive game (for example, an artistic one) and reflective dialogue. The purpose of artphiletics is to provide a person with the opportunity to discover his/her own mental potential and limits and to find his/her place and role in human society, equip him/her with sensitivity to the pain felt by other beings, and prepare him/her for spiritual growth and finding a purpose in life with support from human cultural artefacts, particularly art (Slavík, 1997).

Slavík (1997, 2001), Slavík, Vladimír Chrz, and Stanislav Štech (2013) emphasises the new dimension that artphiletics brings to the educational process and by which it distinguishes itself from ordinary art education: reflection in combination with a constructively conceived dialogue. In the field of goals, artphiletics focuses on learning about art in relation to learning about oneself within a culture and on the development of the social competence of a student by means of artistic expression. In the field of methods, artphiletics is based on a combination of artistic expressive games and what is termed a reflective dialogue. This means that 
artphiletics considers the artistic work of a student to be the first cognitive step, which should be followed by additional steps: reflection and dialogue between students as a source of new knowledge. In this regard, artphiletics is directed towards the development of social and emotional intelligence and towards the cultivation of the ethical values of students, as well as having educational goals in the field of art and culture. The above-mentioned approach means that artphiletics is a pedagogic constructivist and didactic style, directing education towards the development of critical thinking or what is known as higher-level thinking (learning to understand one's own spiritual processes and motives).

It is this combination of expression and reflection that distinguishes artphiletics from art education and makes it more like art therapy. However, artphiletics does not have the goal of treating or clarifying the problems of clients and this distinguishes it from art therapy and makes it more like art education. As a result, artphiletics lies somewhere between psychotherapy, art therapy, and education, or even art education. Artphiletics therefore also focuses on the development of creativity.

Philip J. Carter and Ken Russell (1996) define creativity as a mental process that leads to new solutions, ideas, or products. Vladimír Smékal (2004) characterises creativeness as a psychological activity involving an untraditional approach to objects, an original approach, inventiveness, and the use of unusual associations. John S. Dacey and Kathleen Lennon (1998) mention that Max Wertheimer, as a founder of Gestalt psychology, emphasised creativity as a way to a new viewpoint on a whole issue rather than a new arrangement of its parts.

Dacey and Lennon (1998) mention different views of creativity that have changed considerably over time. From the earliest times till about the Renaissance the level of creativity of an individual was considered a result of God's presence in the widest possible sense. Later heredity was emphasised. A fundamental dispute related to the dominant force in creativity emerged in the early 20th century: is it driven by personal traits or education?

The current majority opinion is that the level of individual creativity is a cumulative result of biological and psychological factors and is also influenced by social factors. Dacey and Lennon (1998) refer to five basic sources of the level of creativity: biological features, personality features, cognitive features, micro-social circumstances, and macro-social conditions. From the viewpoint of the educational process, an integrative approach appears to be a functional one, i.e. seeing it as a set of biological, psychological, and social factors. It should be the task of educational institutions to support creativity as one of the factors that have a positive influence on thinking.

J. P. Guilford (1967) distinguished between two types of thinking: convergent and divergent. Divergent thinking in relation to problem solving allows various alternatives to be looked for, from which the best is selected using convergent thinking. Divergent thinking, which is closely related to creativity, has the following components according to J. P. Guilford (1967):

- fluency (of ideas);

- flexibility (of thinking);

- originality;

- sensitivity (to problems);

- redefining, or the ability to use previous knowledge in a new way;

- elaboration, i.e. the creation of functional details during the problem-solving process. 
To establish the level of fantasy, we most often use the Torrance figural test of creative thinking (Jurčová, 1984). This test is used for the evaluation of imagination, creativeness, and original ways of solving art tasks. The test is based on Gestalt psychology. The basic piece of knowledge from Gestalt psychology that is closely related to the topic can be defined as follows: incomplete drawings create tension that results in completing the drawing in the simplest possible way. To create an original response, it is necessary to handle the tension that leads towards the simplest solution and opt for a variant that prolongs the search. Within the Torrance figural test an individual is given an art project in which the most common and seemingly clear solution is "suggested". The tasks require thinking of an original solution to the task, i.e. overcoming the tension leading to the simplest solution. The individual is free to accept the "suggested" solution and make the task unambiguous, or he/she can put the solution that is offered aside and seek another, hidden meaning, i.e. may accept the fact that the processing of the task may be multivalent.

In relation to the present research it is useful to define the term "ambiguous stimulus". This term became the theoretical basis for the issues researched here.

An ambiguous stimulus is an element of expression that calls for completion into a content whole, which is called a good shape (Slavík et al., 2013; Tuck, 2010). For an ambiguous stimulus to be completed, it must be interpreted according to its content or concept as a part of a certain semantic area. Thus, the quality of the response to an ambiguous stimulus is conditioned upon the size of the semantic area, freedom of choice from the area, and the level of one's handling of means of expression (Slavík et al., 2013; Todorović, 2011).

We can commonly come across various ambiguous stimuli. The responses of individuals to the stimuli range from fear, helplessness, inability to react, and an unambiguous response to joy through discovering and searching for all the possible reactions. Art is one of the ambiguous stimuli, in most cases giving the respondent enough space for his/her imagination. Following what is written above, we can divide the responses into three groups: a tendency to unambiguousness, a tendency to multiple meanings, and inability to respond.

Apart from these, the respondent's reaction depends on several basic factors: the specific quality of the stimulus, the context in which the stimulus is handled, previous experience and disposition, and the momentary state of the individual (Potměšilová, 2015). The context of the handling of the stimulus includes cultural customs, the language context, and the circumstances of presentation. A tendency to unambiguousness, a tendency to multiple meanings, and inability to respond to an art stimulus can be present simultaneously, but with different weights. Which variant will prevail depends on the above-mentioned factors.

With the unambiguous response, a concept will emerge in the respondent's mind that is supposed to capture the stimulus. However, non-verbal operations are at work at the same time. The stimulus is perceived as an index - part of the whole, leading to a "good shape" (Carlson et al., 2009). During this completion process simultaneous infralogical and logical operations are taking place (Slavík et al., 2013; Currie \& Ravenscroft, 2002).

The tendency to unambiguousness when interpreting expressive artefacts is due to the metaphoric nature of expression. When encountering a metaphor an individual is led to use and mix the contents of differing experience. This specific process is called blending (Slavík et al., 2013). Metaphor is not burdened by a stabilised language convention, and provides 
space for ambiguous capture, allowing the application of the unique experience of the subject, i.e. also for inter-subjective differences in interpretation (which is known as the interpretation spread) (Slavík et al., 2013).

In connection with the perception of an ambiguous stimulus it is necessary to mention Zenon Pylyshyn's term "cognitive penetrability" (Currie \& Ravenscroft, 2002; Slavík et al., 2013). Pylyshyn defines it as the level of dependence of the psychological process on conceptual and rational-logical dealing with the content. The possibility of cognitive penetrability is thus due to conscious intention, conceptual rational-logical operations, and expressions with the same content as the vision. The client's product also helps to provide a deeper understanding of the meanings of visual metaphors (Kaplan, 2000). Cognitive penetrability is a precondition for the inter-subjective mediation of ideas in words, or non-verbal expressions (understanding), because it is a precondition for the intentional expression of ideas. Therefore, to what extent and quality an idea is expressed in relevant words or non-verbal signals is important; this quality is then put to the test in communication with others. The respondent is expressing his/her understanding of the idea, confirming the possibility of understanding others.

Art provides one of the possible forms of human interaction. The interaction is based on understanding what the viewer is telling the audience and the understanding is influenced by a number of factors. One of the factors which have an effect on the level of understanding of an art stimulus is the cultural environment in which the individual lives. Considering the ever more frequent encounters between different cultures, this aspect can be seen as an important one for further research (McNiff \& Barlow, 2009; Robb, 2015).

\section{Study goal}

The goal of this study is to find paths and demonstrate the potential for the use of the method of an ambiguous stimulus during the description of the creativity of an individual. The study also succeeded in testing the above-mentioned technique in two countries.

Because this is a follow-up research study, it was not necessary to do pilotage in this case. We have been working with an ambiguous stimulus systematically since 2005 . The first part of the research was devoted to mapping the reactions to the ambiguous stimulus of a respondent from the CZR, further wondering whether there are cultural differences in response to an ambiguous stimulus (Potmesilova, Sobkova, \& Fojtíkova Roubalova, 2014; Potměšilová \& Buqiong, 2015).

The different numbers of respondents during this phase of the work are not detrimental, because the purpose of this part of the research was not to provide generally valid differences for individual cultural environments, but to demonstrate the established differences and provide an opportunity for scientific questions as a basis for continuing the research. The research on "creativity in the artphiletics process" presented here was based on the principles of the Torrance figural test. The respondents were given the task of utilising an ambiguous stimulus as the basis for an artistic response. 


\section{Methodology}

A creative task was chosen as the research tool, developed in accordance with the principles of artphiletics (Slavík, 2001), and according to the principles of the Torrance test of creative thinking (Jurčová, 1984). The task has been used by the present authors' in the CZR for more than nine years. More than 600 responses have been collected. Individual responses have been recorded and processed using the grounded theory method. The method was used to create content categories into which the responses could be divided, and subsequently other categories were developed (number of details, overall composition, location of the ambiguous stimulus, use of colours...) that can be evaluated, thus allowing a description of the situation.

Using the opportunity presented by the authors' professional activities, the task was given not only to respondents from the CZR, but additionally to respondents from Poland.

A qualitative and quantitative methodology was chosen for the implementation of the research. On the basis of practical experience and the above-mentioned theory, the following research question was formulated: Are there culture-based differences in the perception of an ambiguous stimulus? If so, what are they?

\subsection{Data collection methods}

The principal data collection method chosen was the analysis of the results of activity. This method was supported by two more approaches:

- visible and non-aligned observation,

- semi-structured interviews.

Every respondent received the part of the picture shown on the left below (Figure 1), representing a section or a quarter of a larger picture (Figure 2).

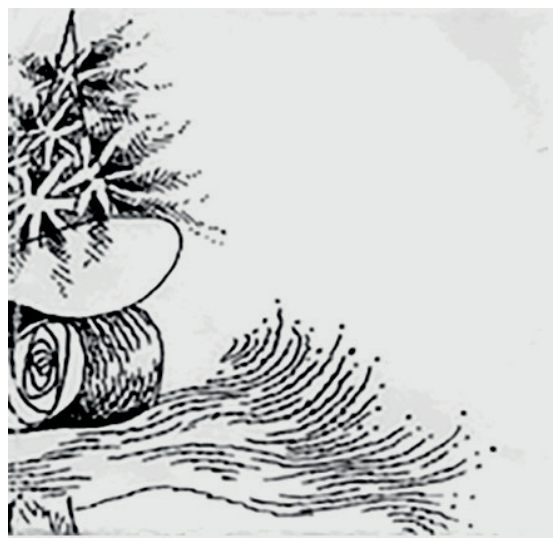

Figure 1. Picture ${ }^{1}$ used for research

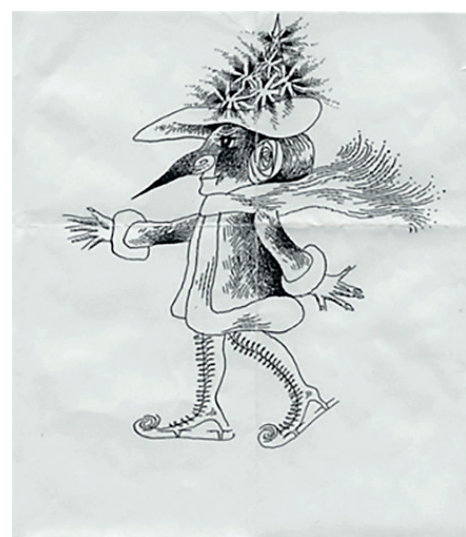

Figure 2. The original picture

\footnotetext{
${ }^{1}$ At the time of the beginning of the research in 2005, the original picture was freely available on the Internet without an author's release. Given the current rules, we do not mention the original picture in the study. The image used for research purposes was modified by the authors of this study.
} 
In addition to this picture, referred to below as the original motif or ambiguous stimulus, every respondent received a blank sheet of white paper (A4), crayons of 24 different colours, and glue.

After the art materials had been handed out, the following instructions were given:

"You have received part of a picture. First, look at it carefully; you can also turn it. As soon as you think the picture reminds you of anything, try to complete it. Glue the part of the picture to the piece of white paper you have received. You can work with the picture in any way you like. You can use any of the art materials you have been given".

In the CZR the instructions were given in the Czech language. In Poland the instructions were given in the Polish language.

The respondents were observed as they worked in terms of their handling of the picture and the speed of their solution. The time needed for the work was adapted to the characteristics of the group of respondents and ranged from 10 minutes to half an hour. The work on the picture was followed by a semi-structured interview, in the context of which the following questions were asked:

1. Is your work the result of an instant idea? Did you know immediately what you would do?

2. Was this idea the only one or did you have more ideas about what to do?

3. If you had more ideas, why did you choose this solution?

Further questions were asked on the basis of each particular case and situation, developing from the previous conversation. At the end of the session the respondents were shown the whole picture from which the section had been cut out for them to work with. After they had been shown the whole picture, a short discussion usually developed from which further valuable information could be derived.

\subsection{Respondents}

As already mentioned above, the survey respondents were from two different countries. They were university students aged from 20 to 35 years.

Table 1. Countries - respondents

\begin{tabular}{|l|c|}
\hline \multicolumn{1}{|c|}{ Country } & The number of respondents \\
\hline Czech Republic & 600 \\
\hline Poland & 143 \\
\hline
\end{tabular}

The size of the sample of respondents from the CZR is determined by the long-term nature of the research and entitles the authors to state that fixed categories have already been established for the Czech population. In the CZR, data collection is still in progress, but the varieties of categories are no longer changing, and nor is the percentage of individual responses changing. The number of respondents from Poland makes it possible to create a more accurate picture of each category at the present time (see Table 1). Because of the differences in the number of respondents, the other data is always given in percentages. In all four cases, three-quarters of the sample were women. 


\subsection{Processing methods and data analysis}

The data processing was based on the method of systematic storage and fixation of qualitative data. The pictures created by the respondents were stored by date and collection point for further analysis. Notes were taken from the observations and interviews, dated, provided with information about the place of the data collection, and attached to the individual pictures.

The analysis of the data obtained from the first, second, and third research sessions was performed first by the method of pattern identification and then by simple listing. Qualitative methods were complemented with descriptive statistics, which is a quantitative method. The method of pattern identification was used to find repeated themes - categories - which, if found, were recorded. Further pictures were then included under these defined categories. This method was followed by a simple listing method, by means of which we tried to find how often each category occurred and what its proportion was in comparison to the other categories. For the sake of increased transparency, the qualitative methods were complemented with descriptive statistics which organised numbers and percentages relating to the individual categories into tables and diagrams. The simple listing and descriptive statistical methods thus became a significant aid in the interpretation of the qualitative data.

\subsection{Presentation of research results}

The content categories which were constructed on the basis of the reactions of the respondents from the CZR were gradually upgraded during the research period.

As already mentioned above, the Czech cohort is no longer changing in terms of individual categories. In the Polish sample, the individual categories have already stabilised, but the percentage of individual solutions is still changing.

Both Table 2 and Figure 2 show that the motif "Christmas" was the most common solution in both sets of respondents. This category occurs in about $50 \%$ of cases in the CZR, and as Advent approaches sometimes up to $80 \%$ of cases. In the Polish case, the scattering is from $9 \%$ to $63 \%$ and the frequency increases at Advent. However, the overall frequency is lower than in the CZR. The second most common solution was reactions that could be grouped

Table 2. Occurrence of categories (POL - Poland, CZR - Czech Republic)

\begin{tabular}{|l|c|c|}
\hline & POL $\%$ & CZR \% \\
\hline Nature (a tree, a log, wood, a willow tree by a lake) & 27 & 25 \\
\hline Underwater world & 1 & 15 \\
\hline Christmas & 38 & 50 \\
\hline A figure & 8 & 6 \\
\hline An original solution & 15 & 3 \\
\hline An inadequate solution & 4 & 1 \\
\hline Ship & 1 & 0 \\
\hline Animal & 6 & 0 \\
\hline TOTAL & 100 & 100 \\
\hline
\end{tabular}




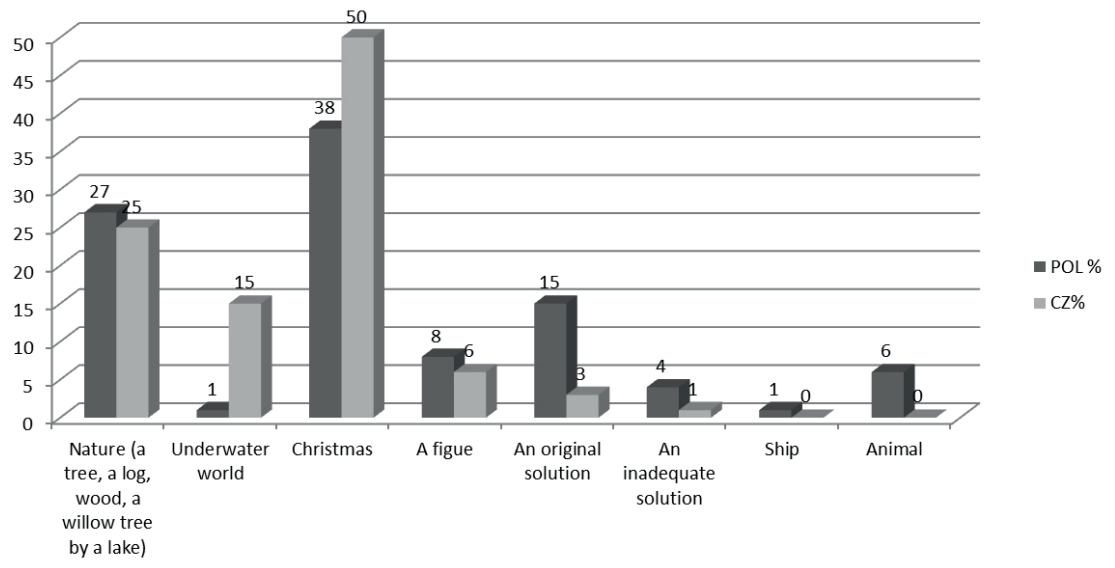

Figure 2. Occurrence of categories

into a group of natural motifs. Here, the smallest differences between the CZR and Poland can be observed. Solutions belonging to the "figure" category also have a similar percentage representation. It was either part of a face or a complete figure.

Significant differences can be observed in the frequency of solutions generally named the "underwater world" category. The frequency of these reactions is higher in the CZR. The "ship" and "animals" categories can be considered a specific cultural difference. These two categories did not appear in adult respondents anywhere in the CZR. Respondents have rarely found a solution that can be categorised as "animal" but there are only a few of these solutions in the "original solution" category (Potměšilová, 2015). The differences in the occurrence of inadequate solutions are not as significant as the occurrence of original solutions. The frequency of original solutions is $15 \%$ in Poland. Among the respondents from the CZR, the share of "an original solution" is between 3 and 4\%, which corresponds to one edge of the normal distribution of a given phenomenon in the society. The Polish respondents showed significantly higher numbers of "original solutions" not only in relation to the number of inadequate responses, but also in comparison to the respondents from the CZR. All the categories that were evaluated: For all reactions, the following categories were further evaluated:

- colour pattern;

- text (story);

- merger of part of the picture with the art solution;

- details;

- overall concept.

The first category was equally present in all four groups in about $25 \%$ of cases. The second category was minimally present in all four groups in about $1 \%$ of cases. The third category scored in all four groups in about $5 \%$ of cases. The need for details was remarkable among the respondents from Poland (80\%). About 10\% of the Czech respondents expressed this need. The overall concept was again remarkable among the respondents from Poland (70-80\%). About $40-50 \%$ of the Czech respondents expressed such a need. 


\section{Conclusions}

In the present study, other partial results are presented, namely a comparison of two countries (the CZR and Poland). The aforementioned results show that there are culturally different differences in the perception of an ambiguous stimulus among the respondents in the CZR and Poland. The following basic differences can be named: different categories of reactions and a higher incidence of original solutions. Different percentages can be included in the categories, which are identical for both the Czech and Polish respondents. The occurrence of different categories was confirmed by the fact that categories from one cultural environment are not transferable between cultures (Potměšilová, 2015).

In the case of the responses from Poland, they were initially classified into the "Czech categories". However, it gradually became clear that this was not suitable and that new categories should be established for each country. This became especially clear in the "unique solution" categories - what is unique in one country is a perfectly normal solution in other countries. We were able to commence analysing and subsequently forming conclusions on the basis of this finding.

With regard to a higher number of original solutions, there are two possible explanations: a truly higher inclination towards more original approaches to an ambiguous stimulus or - considering the specific responses perhaps a more likely explanation - a new content category that is typical of Polish culture. The individual "original solutions" largely presented various fairy tales or supernatural or dream beings. Particular uses were markedly different (parts of items of clothing, the face, the body...). Following the markedly different uses, the resulting pictures were included in the "original solution" category. However, it will be this very fact that will become the object of further research.

The most interesting difference in frequency can be considered in the Christmas category. Czechs and Poles are two European, Slavic nations that have numerous historical similarities and are culturally close. Despite this proximity, however, it is necessary to respect the differences. Such differences are explained by Eva Večerková and Věra Frolcová (2010), who mention that the occurrence of a Christmas tree as a symbol differed to a large extent around Europe. It has taken the Christmas tree some time to prevail. It was recorded in Poland at the beginning of the 19th century, but mainly in German households, more specifically among Evangelists. In some areas of Poland, a non-deciduous oak twig was used instead for a long time (Večerková \& Frolcová, 2010). Christmas trees came to the Czech lands in the 1820s, but as those authors explain, the tradition became fully developed only a hundred years later. It may be possible to explain the major differences in the "Christmas" category on the basis of this explanation.

\section{Practical usage}

The technique presented here can be used in two ways in practice: as a way to develop the creativity of clients or as a test of creativity. In the first case, the selected drawing can be analyzed with the client. In the continuation of the interview, it is possible to look for other alternatives. In diagnostic use, it is possible to see whether the client is inclined to work with the first stimulus and whether their response is creative or will be one of the common solutions. 


\section{Study limits}

In the case of the Polish respondents, these are currently partial results. For Polish respondents, these are partial results. The categories of themes are steady, but the number of individual drawing reactions is changing so far, so it is not possible to infer from the results the final state.

\section{Funding information}

Funding: this work was supported by grants IGA_CMTF_ 2018_03, IGA_PdF_2018_008 and US-WEINOE 1S-1213-001-1-10-0.

\section{References}

Aron Rubinová, J. (Ed.). (2008). Př́stupy v arteterapii: teorie \& technika. Praha: Triton.

Campbell, J. (1998). Techniky arteterapie ve výchově, sociální práci a klinické praxi. Praha: Portál.

Carlson, N. R., Heth, C. D., Miller, H., Donahoe, J. W., Buskist, W., \& Martin, G. N. (2009). Psychology: The science of behavior. Boston: Allyn \& Bacon.

Carter, J. Ph., \& Russell, K. (1996). Challenging IQ puzzles. New York: Sterling Juvenile.

Case, C., \& Dalley, T. (2014). The handbook of art therapy. New York: Routledge. https://doi.org/10.4324/9781315779799

Currie, G., \& Ravenscroft, I. (2002). Recreative minds: imagination in philosophy and psychology. Oxford, New York: Clarendon Press, Oxford University Press. https://doi.org/10.1093/acprof:oso/9780198238089.001.0001

Dacey, J. S., \& Lennon, K. H. (1998). Understanding creativity: the interplay of biological, psychological, and social factors. San Francisco, CA: Jossey-Bass Inc.

Guilford, J. P. (1967). The nature of human intelligence. Series: McGraw-Hill Series in Psychology. New York: McGraw-Hill Education.

Jurčová, M. (1984). Torranceho figurálny test tvorivého myslenia: praktická čast. Bratislava: Psychodiagnostické a didaktické testy.

Lowenfeld, V., \& Brittain, W. L. (1987). Creative and mental growth. New York: Macmillan.

Kaplan, F. F. (2000). Art, science and art therapy: repainting the picture. London and Philadelphia: Jessica Kingsley Publishers.

Karkou, V., \& Sanderson, P. (2006). Arts therapies: a research-based map of the field. Edinburgh: Churchill Livingstone.

McNiff, Sh., \& Barlow, G. C. (2009). Cross-cultural psychotherapy and art. Art Therapy: Journal of the American Art Therapy Association, 26(3), 100-106. https://doi.org/10.1080/07421656.2009.10129379

Malchiodi, C. A. (Ed.). (2012). Handbook of art therapy. New York: The Guilford Press.

Potmesilova, P., Sobkova, P., \& Fojtíkova Roubalova, M. (2014). Effect of cultural differences in reaction of students to ambiguous art stimulus. Open Journal of Social Sciences, 2, 58-67. https://doi.org/10.4236/jss.2014.211008

Potměšilová, P. (2015). The reaction of children with hearing impairment to an ambiguous stimulus. E-Pedagogium, 2, 159-174.

Potměšilová, P., \& Buqiong. (2015). Ambiguous stimulus in the educational process of pupils with hearing impairment, Paidagogos. Journal of Education in Contexts, 15(1), 158-170. 
Robb, M. (2015). Using art therapy with diverse populations: crossing cultures and abilities. Art Therapy: Journal of the American Art Therapy Association, 32(1), 40-41. https://doi.org/10.1080/07421656.2015.995035

Slavík, J. (1997). Od výrazu k dialogu ve výchově: artefiletika. Praha: Karolinum.

Slavík, J. (2001). Umění zážitku, zážitek umění (teorie a praxe artefiletiky). I díl. Praha: Univerzita Karlova - Pedagogická fakulta.

Slavík, J., Chrz, V., \& Štech, S. (2013). Tvorba jako způsob poznávání. Praha: Universita Karlova v Praze.

Smékal, V. (2004). Pozvání do psychologie osobnosti. Člověk v zrcadle vědomí a jednání. Brno: Barrister \& Principal.

Spaniol, S. (2012). Art therapy with adults with severe mental illness. In C. A. Malchiodi (Ed.), Handbook of art therapy (pp. 288-301). New York: The Guilford Press.

Sutherland, J. (2011). Art therapy with families. Journal of Individual Psychology, 67(3), 292-304.

Todorović, D. (2011). What is the origin of the gestalt principles? Humana Mente: Journal of Philosophical Studies, 17, 1-20.

Tuck, M. (2010). Gestalt principles applied in design. Retrieved from https://www.webfx.com/blog/webdesign/gestalt-principles-applied-in-design/

Večerková, E., \& Frolcová, V. (2010). Evropské Vánoce v tradicích lidové kultury. Praha: Vyšehrad.

\section{KŪRYBINIŲ REAKCIJŲ I DVIPRASMES PASKATAS KULTÜRINIAI SKIRTUMAI}

\section{Petra POTMĚŠILOVÁ, Miloň POTMĚŠIL}

\section{Santrauka}

Meno terapija Čekijoje taikoma nuo XX a. 6-ojo dešimtmečio, vienintelis dalykas, kuris, laikui bėgant, pakito, yra tikslinè grupe, kuriai taikoma meno terapija. Šiuo metu meno terapija pasitelkiama trijose pagrindinèse srityse: psichologijoje, socialiniame darbe ar, tiksliau tariant, specialiajame ugdyme. Šio straipsnio tikslas - atskleisti specifinius kultūrinius skirtumus, taikant meno terapijos procedūras švietimo srityje, ypač dirbant su kūrybiškumo reiškiniu. Tikslinę tyrimo grupę sudaro universiteto studentai iš Lenkijos ir Čekijos. Visi studentai buvo supažindinti su dviprasmemis paskatomis, kurias jie turejo atliepti iš meninès perspektyvos. Tada individualios meninès reakcijos buvo suklasifikuotos ị tam tikras kategorijas, o kultūriniai skirtumai - įvertinti ir aprašyti.

Reikšminiai žodžiai: dviprasmė paskata, meno filetika, artphiletics, kognityvinis pasiekiamumas, kūrybiškumas, kultūriniai aspektai, švietimo procesas. 